\title{
Molecular Targeted Therapies for the Treatment of Leptomeningeal Carcinomatosis: Current Evidence and Future Directions
}

\author{
Dae-Won Lee ${ }^{1}$, Kyung-Hun Lee ${ }^{1,2}$, Jin Wook Kim ${ }^{3}$ and Bhumsuk Keam ${ }^{1,2, *}$ \\ 1 Department of Internal Medicine, Seoul National University Hospital, Seoul 03080, Korea; \\ silver2sky@hanmail.net (D.-W.L.); drleekh@gmail.com (K.-H.L.) \\ 2 Cancer Research Institute, Seoul National University College of Medicine, Seoul 03080, Korea \\ 3 Department of Neurosurgery, Seoul National University Hospital, Seoul 03080, Korea; \\ wook616@hanmail.net \\ * Correspondence: bhumsuk@snu.ac.kr; Tel.: +82-2-2072-7215; Fax: +82-2-2072-7379 \\ Academic Editor: Dario Marchetti \\ Received: 19 May 2016; Accepted: 28 June 2016; Published: 5 July 2016
}

\begin{abstract}
Leptomeningeal carcinomatosis (LMC) is the multifocal seeding of cerebrospinal fluid and leptomeninges by malignant cells. The incidence of LMC is approximately $5 \%$ in patients with malignant tumors overall and the rate is increasing due to increasing survival time of cancer patients. Eradication of the disease is not yet possible, so the treatment goals of LMC are to improve neurologic symptoms and to prolong survival. A standard treatment for LMC has not been established due to low incidences of LMC, the rapidly progressing nature of the disease, heterogeneous populations with LMC, and a lack of randomized clinical trial results. Treatment options for LMC include intrathecal chemotherapy, systemic chemotherapy, and radiation therapy, but the prognoses remain poor with a median survival of $<3$ months. Recently, molecular targeted agents have been applied in the clinic and have shown groundbreaking results in specific patient groups epidermal growth factor receptor (EGFR)-targeted therapy or an anaplastic lymphoma kinase ( $A L K)$ inhibitor in lung cancer, human epidermal growth factor receptor 2 (HER2)-directed therapy in breast cancer, and CD20-targeted therapy in B cell lymphoma). Moreover, there are results indicating that the use of these agents under proper dose and administration routes can be effective for managing LMC. In this article, we review molecular targeted agents for managing LMC.
\end{abstract}

Keywords: leptomeningeal carcinomatosis; lung cancer; breast cancer; molecular targeted agent

\section{Introduction}

Leptomeningeal carcinomatosis (LMC) is the multifocal seeding of leptomeninges by malignant cells. The incidence of LMC is approximately $5 \%$ of patients with malignant tumors and the rate of identification is increasing due to improvements in neuroimaging technologies and advances in cancer treatments [1-3]. Small cell lung cancer (SCLC) and melanoma exhibit the highest leptomeningeal spread rates. About $11 \%$ of SCLC patients develop LMC, and while meningeal involvement is clinically suspected in $10.6 \%$ of malignant melanoma patients, it is actually confirmed during autopsy in $52 \%$ of these cases $[4,5]$. However, most cases of LMC arise in breast cancer and non-small cell lung cancer (NSCLC) because of the high incidences of these cancers $[3,6,7]$.

The prognosis of LMC remains very poor with a median overall survival of $<3$ months, but prognosis is influenced by the primary tumor type [3,7-10]. In a systemic review of clinical studies, patients with LMC from breast cancer show better survival rates (15.3 weeks) compared to those from lung cancer (8.7 weeks) [10]. Treatments are aimed at improving or stabilizing neurologic symptoms and prolonging survival. Radiation therapy, systemic chemotherapy, and intrathecal chemotherapy 
are primary treatments for LMC. Only six randomized clinical trials have been conducted for LMC and a standard treatment remains to be established [8,11-15]. Advances in molecular targeted agents have prolonged survival, especially in patients with lung cancer harboring epidermal growth factor receptor (EGFR) mutations or anaplastic lymphoma kinase $(A L K)$ rearrangement, and in patients with breast cancer harboring human epidermal growth factor receptor 2 (HER2) amplification. The use of proper molecular targeted agents can prolong survival of patients with LMC relative to historical examples from pre-molecular targeted agents era [16-19]. In this article, we review recent results from the use of molecular targeted agents and discuss novel approaches to treating LMC.

\section{Clinical Manifestation and Diagnosis}

LMC usually occurs in patients with prolonged disease periods and disseminated systemic cancer. However, $5 \%-10 \%$ of LMC occurs in patients who show no evidence of systemic disease [20]. LMC presents with signs and symptoms of multifocal neuraxis disease. In a systemic review of 456 patients with LMC, common clinical manifestation included cranial nerve palsies $(75 \%)$, headache $(66 \%)$, cerebral disturbances $(66 \%)$, spinal nerve symptom $(60 \%)$, mental change $(45 \%)$, limb weakness $(44 \%)$ and difficult walking (33\%) [21]. Nausea and vomiting also occurred for $20 \%$ of patients.

The gold standard for diagnosing LMC is cerebrospinal fluid (CSF) examination through lumbar puncture. While lumbar puncture is a relatively safe procedure, there can be severe complications such as cerebral herniation, meningitis, and bleeding in epidural or subdural spaces. Before performing a lumbar puncture, clinicians should be aware of any bulky intracranial diseases or bleeding diathesis. Initial CSF cytology is positive in 50\% of cases and repeated spinal fluid analyses up to three times maximum yields up to $90 \%$ positive cytology $[7,22]$. Hence, repeated CSF cytology examination is needed for cytology-negative, clinically-suspicious cases. Elevated CSF opening pressure (found in $42 \%-70 \%$ of patients), high CSF white blood cell (WBC) counts $(48 \%-64 \%)$, elevated CSF protein levels (59\%-80\%), and low CSF glucose levels (22\%-58\%) can support an LMC diagnosis in CSF cytology-negative patients $[6,17,18,22,23]$. There is also evidence that biochemical markers such as vascular endothelial growth factor (VEGF), CYFRA 21-1, neuron-specific enolase (NSE), and carcinoembryonic antigen (CEA) in the CSF can aid LMC diagnosis [24,25]. Detecting malignant cells in CSF by assessing circulating tumor cells have shown high sensitivity in LMC of breast cancer patients [26]. In addition, CSF-derived cell-free circulating tumor DNA has shown to complement the diagnosis of LMC [27]. However, use of such methods is limited due to poor sensitivity, poor specificity, and the lack of an accurate cutoff level. Clinicians should measure CSF opening pressure and obtain CSF cytology, cell counts, protein levels, and glucose levels in suspected LMC patients.

Magnetic resonance imaging (MRI) has become an important diagnostic tool for LMC following improvements in the quality of neuroimaging [6,28-30]. MRI is effective in LMC diagnosis for $83 \%-85 \%$ of solid tumor cases, but this sensitivity drops to $20 \%-50 \%$ in hematologic malignancies $[6,28,31]$. As observed through MRI, pial enhancement and nodularity are the most common features of LMC along with nodular disease, neural enhancement, and white matter changes [29]. MRI results that do not show LMC features are not sufficient to exclude an LMC diagnosis in clinically suspected cases. However, in patients with suspected disease, MRI alone is adequate for LMC diagnosis. MRI should be performed before lumbar puncture because meningeal irritation due to the puncture could yield false positive MRI results.

In suspicious patients, the LMC diagnosis could be made by CSF examination or MRI imaging. Recently, a metabolomic approach showed efficacy for LMC diagnosis [32] where the use of five metabolites from CSF resulted in diagnostic sensitivity and specificity of over $90 \%$. Metabolomic approaches could augment current diagnostic modalities for LMC in the near future.

\section{Treatment}

Treatment goals for LMC are to improve neurologic symptoms and prolong survival. Because eradication of LMC is not yet possible, clinicians should carefully assess a patient's overall clinical status 
to determine the degree or extent of treatment. The standard of treatment for LMC has not yet been established due to low incidence rates, the rapidly progressing nature of the disease, heterogeneous LMC populations, and a lack of sufficient randomized trial-based results. Treatment options for LMC include intrathecal chemotherapy, systemic chemotherapy and radiation therapy. However, the selection of these treatment modes is based on limited numbers of randomized clinical trials and most evidence on treatment effectiveness comes from non-randomized or observational studies.

\subsection{Intrathecal and Systemic Chemotherapy}

Achieving therapeutic dose levels of chemotherapeutic agents in the CSF space is challenging because of the blood-brain barrier (BBB) and the blood-CSF barrier [33,34]. BBB permeability is increased in patients with brain metastases through tumor perturbation and by the effect of antigen-rich sites within brain metastases [34,35]. High-dose methotrexate (MTX) and cytosine arabinoside (Ara-C) have historically been used as systemic chemotherapeutic agents to treat LMC, but results from systemic MTX and Ara-C use are minimal from lung cancer and breast cancer cases. These agents also show high toxicity and low efficacy for managing extracranial lesions. A pilot study of bevacizumab combined with etoposide and cisplatin in breast cancer patients with LMC showed promising efficacy and additional studies are needed to validate this finding [36].

Intrathecal chemotherapy was introduced in the 1970s to circumvent BBB and blood-CSF barrier issues. Chemotherapeutic agents can be delivered directly into the CSF space by lumbar puncture or through an intraventricular catheter. Intraventricular catheters, such as an Ommaya reservoir, are preferred because they are more comfortable for patients and are effective at delivering a uniform distribution of drug into the CSF space [37,38]. Distribution of the chemotherapeutic agent is dependent on CSF flow dynamics and a CSF flow scan should be performed before intrathecal chemotherapy [39].

Since the advent of the intrathecal chemotherapy, the most commonly used agents for intrathecal chemotherapy have been MTX, Ara-C, and thiotepa [8,12-14]. These drugs have shown efficacy as single agents or in combinations. MTX showed similar median survival rates (15.9 weeks vs. 14.1 weeks) to thiotepa in a study where 52 assessable patients were treated [12]. However, mucositis and neurologic complications were more common in patients who received MTX. Intrathecal sustained-release Ara-C was compared to intrathecal MTX in 61 LMC patients [14], but there was no significant difference in median survival between sustained-release Ara-C and MTX (105 days vs. 78 days, respectively; $p=0.15$ ). However, median time to neurological progression favored sustained-release Ara-C over MTX (58 days vs. 30 days, $p=0.007$ ). In a single-group, retrospective study a three-drug combination (intrathecal MTX, Ara-C, and hydrocortisone) showed more favorable effects than intrathecal MTX alone [40]. However, the combination of intrathecal MTX and Ara-C was not better than intrathecal MTX alone in a randomized clinical study [8]. Current evidence cannot support a preferable intrathecal chemotherapeutic agent from MTX, Ara-C, and thiotepa. Until more evidence is gathered, using any of the three agents is acceptable for managing LMC. Common complications from intrathecal chemotherapy include chemical aseptic meningitis, which occurs in $>40 \%$ of patients [41]. Symptoms can be managed in an outpatient setting with oral antipyretics, antiemetics, and corticosteroids [20].

\subsection{Radiotherapy and Surgery}

Radiation therapy plays a critical role in brain metastases. However, whole brain radiotherapy did not improve survival in 125 lung cancer patients with leptomeningeal metastasis [42]. CSF fluid circulates from the ventricular system of the brain to the spinal cord and an extended radiation field is needed to treat LMC, which may result in significant radiation toxicity. Radiation therapy plays a limited role in managing LMC and is typically only used to correct CSF flow by focal mass or debulking mass adjustments that facilitate intrathecal chemotherapy efficacy [43]. Debulking surgery is required in cases where a large mass is present. Intraventricular catheters (e.g., Ommaya reservoirs) may be 
implanted in patients who are preparing for intrathecal chemotherapy. Ommaya reservoir placement is a safe procedure, and both frameless or frame-based techniques are safe and accurate [44].

\section{Molecular-Targeted Agents in Leptomeningeal Carcinomatosis (LMC)}

\subsection{Lung Cancer Patients with Epidermal Growth Factor Receptor (EGFR) Mutations}

NSCLC can be classified into several subtypes based on genetic profile. Mutations in the EGFR gene and rearrangement of the ALK gene are the two most studied NSCLC genetic profiles. EGFR mutations are found in $10 \%-15 \%$ of Caucasian NSCLC cases and $30 \%-40 \%$ of Asian NSCLC cases $[45,46]$. Identifying the mutation status of the EGFR gene is important because patients with $E G F R$-activating mutations can be effectively treated with EGFR tyrosine kinase inhibitor (TKI) $[47,48]$. EGFR mutations are also independent positive prognostic factors in NSCLC patients with brain metastases [49,50].

EGFR TKI is a treatment of choice in cases of NSCLC that also have EGFR mutations. Although there have been no randomized clinical trials, retrospective and historical data show that EGFR TKI may be a therapeutic option for LMC (Table 1). In a study by Liao, et al. [51], EGFR-mutated patients who underwent EGFR TKI therapy for LMC showed longer overall survival compared to patients who did not (10.9 months vs. 2.3 months, $p<0.001)$. EGFR TKI can cross the BBB, but only at low levels of $1 \%-3 \%$ [52]. To achieve adequate therapeutic dosing with EGFR TKI in CSF, high-dose EGFR TKI has been tested in NSCLC with LMC. In a phase I study, high-dose gefitinib (750 or $1000 \mathrm{mg}$ daily) resulted in neurologic symptom improvement in 57\% of NSCLC patients who had shown prior response to EGFR TKI [53]. In addition, high-dose erlotinib (200 $\mathrm{mg}$ on alternate days, $300 \mathrm{mg}$ on alternate days, $300 \mathrm{mg}$ every 3 days, $450 \mathrm{mg}$ every 3 days, or $600 \mathrm{mg}$ every 4 days) proved to be effective and safe for managing LMC in patients who failed to respond to standard-dose EGFR TKI [54]. Both erlotinib and gefitinib showed efficacy in NSCLC with LMC. However, compared to gefitinib, erlotinib showed higher CSF concentration ( 28.7 vs. $3.7 \mathrm{ng} / \mathrm{mL}, p=0.0008)$ and penetration levels $(2.77 \%$ vs. $1.13 \%$, $p<0.0001$ ) [52]. In a retrospective study by Lee et al., erlotinib showed higher cytologic conversion rates compared to gefitinib in NSCLC with LMC (64.3\% vs. 9.1\%, $p=0.012)$ [55]. In EGFR-mutated NSCLC with LMC, erlotinib could be more effective than gefitinib, and high-dose EGFR TKI may be an appropriate option.

Table 1. Epidermal growth factor receptor (EGFR) TKI in EGFR (+) non-small cell lung cancer (NSCLC) with leptomeningeal carcinomatosis.

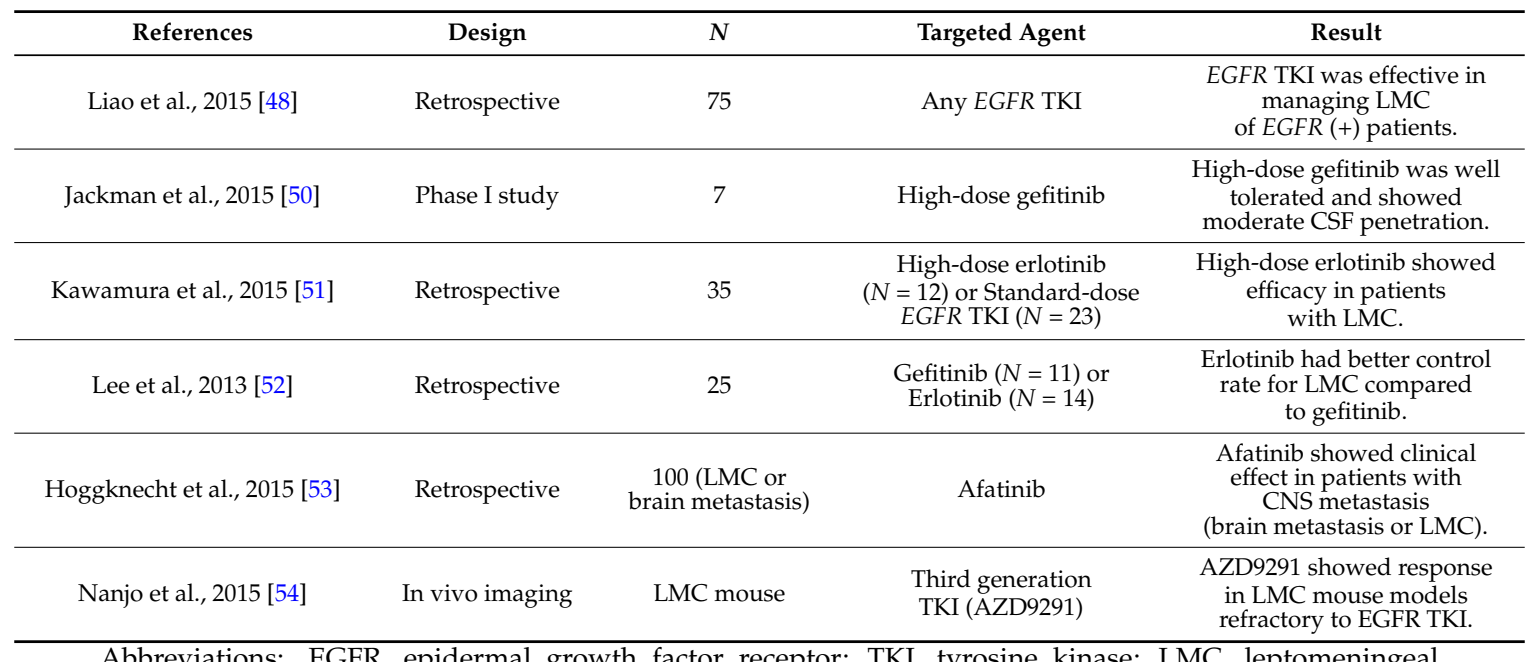

Abbreviations: EGFR, epidermal growth factor receptor; TKI, tyrosine kinase; LMC, leptomeningeal carcinomatosis; CNS, central nervous system. 
Afatinib, an irreversible second-generation EGFR TKI, is approved by the U.S. Food and Drug Administration (FDA) as a treatment option for NSCLC with EGFR mutations. In addition, afatinib is effective for managing brain metastasis or LMC in NSCLC who failed to respond to erlotinib or gefitinib [56]. While the study that determined this did not distinguish between brain metastases and LMC, median time to afatinib failure for patients with CNS metastasis (metastases or LMC) was 3.6 months, which was similar to the effects observed in a matched group of patients without CNS metastasis [56]. In addition, 35\% of observable patients showed cerebral response [56]. However, the efficacy of afatinib in LMC patients who failed high-dose EGFR TKI was not reported. A third-generation EGFR TKI osimertinib (AZD9291) showed efficacy in an in vivo LMC model [57] that was resistant to first- and second-generation EGFR TKI. In addition, osimertinib at $160 \mathrm{mg}$ once daily demonstrates encouraging preliminary safety and activity in heavily pre-treated patients with LMC from NSCLC with EGFR mutations [58]. AZD3759, a potent, CNS-penetrant EGFR TKI, achieved sufficient CNS exposure and demonstrated promising anti-tumor activity in a phase I study [59]. However, evidence is minimal for second- and third-generation EGFR TKI agents, so future studies are needed to confirm the efficacy of these agents in NSCLC with LMC.

\subsection{Lung Cancer Patients with Anaplastic Lymphoma Kinase (ALK) Translocation}

Rearrangement of the $A L K$ gene is found in approximately $4 \%-5 \%$ of NSCLC cases and is more prevalent in nonsmokers, younger patients, and those with adenocarcinoma histology [60]. Detecting $A L K$ rearrangement is important because $A L K$-positive NSCLC is highly sensitive to $A L K$ inhibitors [61]. However, crizotinib, a first-generation $A L K$ inhibitor, poorly penetrates the $\mathrm{BBB}$, so the CNS remains a frequent site of relapse for $A L K$-positive patients treated with crizotinib [62]. In a single-case report, the CSF-to-plasma ratio of crizotinib was only 0.026 [63]. Ceritinib is a second-generation ALK inhibitor that is 20 times as potent as crizotinib, and is effective for $A L K$ positive patients who have progressed while on crizotinib [64]. In another single case, ceritinib showed efficacy against LMC in ALK-positive patients who were resistant to crizotinib (Table 2) [65]. Alectinib is another second-generation ALK inhibitor that is active against crizotinib-resistant disease and in patients with brain metastases [66-68]. Alectinib also showed clinical activity against LMC [69,70]. In a study performed in a knockout mouse model, crizotinib and ceritinib were good transport substrates of human P-glycoprotein (ATP Binding Cassette Subfamily B Member 1, ABCB1), which means crizotinib and ceritinib were efficiently transported out of the brain by ABCB1 [71,72]. In contrast, alectinib was not a good ABCB1 substrate and showed a high brain-to-plasma ratio of $0.63-0.94$ in a mouse model [73]. While prospective data are lacking, evidence from case reports and preclinical studies show that second-generation $A L K$ inhibitors, especially ceritinib, may be treatment options in ALK-positive NSCLC with LMC.

Table 2. Anaplastic lymphoma kinase $(A L K)$ inhibitor in $A L K \quad(+)$ NSCLC with leptomeningeal carcinomatosis.

\begin{tabular}{ccccc}
\hline References & Design & $N$ & Targeted Agent & Result \\
\hline Arrondeau et al., 2014 [60] & Case report & 1 & Ceritinib & $\begin{array}{c}\text { Certinib showed clinical and radiographic } \\
\text { improvement in LMC } \\
\text { for over 5.5 months. }\end{array}$ \\
\hline Ou et al., 2015 [64] & Case report & 1 & Alectinib & $\begin{array}{c}\text { Alectinib induced durable } \\
\text { (>15 months) complete response of LMC. }\end{array}$ \\
\hline Gainor et al., 2015 [65] & Case series & 4 & Alectinib & $\begin{array}{c}3 \text { (75\%) experienced clinical and } \\
\text { radiographic improvement in LMC. } \\
\text { Another one patients had stable } \\
\text { intracranial disease for 4 months. }\end{array}$ \\
\hline
\end{tabular}

Abbreviations: ALK, anaplastic lymphoma kinase; TKI, tyrosine kinase; LMC, leptomeningeal carcinomatosis. 


\subsection{Breast Cancer Patients with Human Epidermal Growth Factor Receptor 2 (HER2) Amplification}

Amplification of HER 2 is observed in approximately $15 \%-20 \%$ of breast cancer patients $[74,75]$. Patients with HER2 amplification have a more aggressive form of the disease, but the introduction of HER2-targeted therapy has improved the prognosis of HER2-positive patients [74,76]. While brain metastasis occurs more frequently in HER2-positive breast cancer, HER2 status is not associated with an increased risk of developing LMC [77]. Because patients with HER2-positive breast cancer liver longer due to improvement in HER2-directed therapies, the incidence of LMC may rise.

Although trastuzumab, a monoclonal antibody that interferes with the HER2 receptor, shows efficacy in HER2-positive breast cancer, its role in LMC is limited due to its large molecular size of $185 \mathrm{kDa}$ [78]. Despite a possible increase in BBB permeability in brain metastases patients, CSF levels of trastuzumab were 300-fold lower than serum levels in breast cancer patients with brain metastases [78]. In a study by Stemmler et al. [79], the serum to CSF trastuzumab ratio in breast cancer patients with brain metastases was 420:1 prior to radiotherapy, 76:1 after radiotherapy, and 49:1 after radiotherapy in patients with concomitant LMC. Because systemic trastuzumab cannot readily cross the $\mathrm{BBB}$, intrathecal trastuzumab has been attempted in cases of HER2-positive breast cancer patients with LMC. Even though there are no phase II/III clinical studies, intrathecal trastuzumab is effective at managing LMC as a single agent or in combination with other agents (intrathecal chemotherapy agents, systemic chemotherapy, or systemic anti-HER2 therapy) [80-84]. A systemic review and pooled analysis of 13 articles (including 17 patients) revealed that intrathecal trastuzumab is a safe and effective option for HER2-postive breast cancer patients with LMC [77]. Intrathecal trastuzumab showed a tolerable safety profile across a wide dose range (single doses of 4-150 mg and total doses of 35-1100 mg) [77]. In a phase I study, intrathecal trastuzumab was given twice a week for 4 weeks, then once a week for 4 weeks, and then every other week until progression of the disease. Under this regimen intrathecal trastuzumab was well tolerated up to $80 \mathrm{mg}$ [85]. Although, there is no standard dose, regimen, or schedule for intrathecal trastuzumab, this agent may be an option of HER2-positive breast cancer patients with LMC.

Lapatinib is a dual TKI of HER1 and HER2 that shows efficacy against metastatic HER2-positive breast cancer that has progressed after trastuzumab treatment $[86,87]$. In a single-arm phase 2 study, lapatinib plus capecitabine was active in managing brain metastases in patients with HER2-positive breast cancer who had not received previous whole brain radiation therapy [88]. However, in a phase III open-label study of lapatinib plus capecitabine versus trastuzumab plus capecitabine, there was no difference in the incidence of CNS metastases between lapatinib-capecitabine and trastuzumab-capecitabine [89]. In addition, there are no reports on lapatinib for treatment of LMC. Currently, there is no evidence of using lapatinib, trastuzumab emtansine, or pertuzumab for managing LMC in patients who have HER2-positive breast cancer. To date, intrathecal trastuzumab is the only targeted treatment that shows efficacy above conventional therapies for managing LMC in HER2-positive breast cancer patients.

\subsection{CD20 Positive Lymphoma Patients and BRAF Mutated Melanoma Patients}

Rituximab is an anti-CD20 monoclonal antibody that is effective for treating diffuse large-B-cell lymphoma (DLBL) [90]. However, because of its large size, when administrated in systemic therapy rituximab CSF levels are only $0.1 \%$ of serum levels, and systemic rituximab therapy did not reduce the risk of secondary CNS occurrence in patients with DLBL [91,92]. Poor CNS penetration has led clinicians to conduct a study using intrathecal rituximab. A phase I study of the intraventricular administration of rituximab in recurrent CNS and intraocular lymphoma has been conducted [93]. Intraventricular rituximab was administered once during the first week and twice per week thereafter for 4 weeks. Intraventricular rituximab was well tolerated in doses up to $25 \mathrm{mg}$, but dose-limiting toxicity (grade 3 hypertension) was experienced in two patients treated at the $50 \mathrm{mg}$ dose level. The estimated distribution half-life and elimination half-life of a $25 \mathrm{mg}$ dose of intraventricular rituximab were 3.0 and $34.9 \mathrm{~h}$, respectively. Among 10 patients, meningeal response was detected in six patients, and one patient exhibited resolution of brain parenchymal lymphoma [93]. In another 
case-series report, intraventricular rituximab showed efficacy in six patients with relapsed CNS lymphoma [94]. Intraventricular injections of 10-40 mg rituximab yielded a total clearance of malignant cells in CSF for three patients and leptomeningeal lymphoma nodules disappeared in another patient [94]. These results illustrate the feasibility of intrathecal rituximab for cases of LMC with CD20-positive Lymphoma.

$B R A F$ inhibitors such as vemurafenib and dabrafenib shows promising effect in $B R A F$ mutated advanced melanoma patients. In a single patient case report, vemurafenib resulted in a significant clinical and imaging response as well as prolonged survival [95]. However, in a report from six melanoma patients, vemurafenib showed low brain-to-plasma ratio of $0.98 \%$ [96]. More evidences are needed to confirm the role of $B R A F$ inhibitors in BRAF mutated melanoma patients with LMC.

\section{Conclusions and Future Directions}

LMC is a devastating disease that occurs in $1 \%-5 \%$ of patients with solid tumors. Conventional therapies including intrathecal chemotherapy, systemic chemotherapy, radiation therapy and surgery have been tested, but the prognosis remains very poor for LMC with a median overall survival of $<3$ months. Recently, molecular targeted agents have been applied to LMC and have shown groundbreaking results. There are also results indicating the use of molecular targeting agents through proper dose and administration are effective for treating LMC in selected patient subgroups (EGFR TKI in EGFR-mutated NSCLC, intrathecal trastuzumab in HER2 positive breast cancer, and intrathecal rituximab in CD20 positive lymphoma). In addition, second- and third-generation $A L K$ inhibitors could play a role in managing LMC in ALK-positive NSCLC patients. However, randomized clinical trial data is needed and the use of new molecular targeting agents requires further investigation. Nevertheless, because there are few options for treating LMC, and these agents show promising results, molecular targeting agents could be a novel therapeutic option for treating LMC in appropriate patient groups.

Author Contributions: Dae-Won Lee and Bhumsuk Keam designed the study; Dae-Won Lee, Jin Wook Kim and Bhumsuk Keam analyzed the data; Dae-Won Lee, Kyung-Hun Lee, and Bhumsuk Keam wrote the paper.

Conflicts of Interest: The authors declare no conflict of interest.

\section{References}

1. Chamberlain, M.; Soffietti, R.; Raizer, J.; Ruda, R.; Brandsma, D.; Boogerd, W.; Taillibert, S.; Groves, M.D.; Le Rhun, E.; Junck, L.; et al. Leptomeningeal metastasis: A response assessment in neuro-oncology critical review of endpoints and response criteria of published randomized clinical trials. Neuro-Oncol. 2014, 16, 1176-1185. [CrossRef] [PubMed]

2. Jaeckle, K.A. Neoplastic meningitis from systemic malignancies: Diagnosis, prognosis and treatment. Semin. Oncol. 2006, 33, 312-323. [CrossRef] [PubMed]

3. Waki, F.; Ando, M.; Takashima, A.; Yonemori, K.; Nokihara, H.; Miyake, M.; Tateishi, U.; Tsuta, K.; Shimada, Y.; Fujiwara, Y.; et al. Prognostic factors and clinical outcomes in patients with leptomeningeal metastasis from solid tumors. J. Neuro Oncol. 2009, 93, 205-212. [CrossRef] [PubMed]

4. Amer, M.H.; Al-Sarraf, M.; Baker, L.H.; Vaitkevicius, V.K. Malignant melanoma and central nervous system metastases: Incidence, diagnosis, treatment and survival. Cancer 1978, 42, 660-668. [CrossRef]

5. Rosen, S.T.; Aisner, J.; Makuch, R.W.; Matthews, M.J.; Ihde, D.C.; Whitacre, M.; Glatstein, E.J.; Wiernik, P.H.; Lichter, A.S.; Bunn, P.A., Jr. Carcinomatous leptomeningitis in small cell lung cancer: A clinicopathologic review of the national cancer institute experience. Medicine 1982, 61, 45-53. [CrossRef] [PubMed]

6. Clarke, J.L.; Perez, H.R.; Jacks, L.M.; Panageas, K.S.; Deangelis, L.M. Leptomeningeal metastases in the mri era. Neurology 2010, 74, 1449-1454. [CrossRef] [PubMed]

7. Wasserstrom, W.R.; Glass, J.P.; Posner, J.B. Diagnosis and treatment of leptomeningeal metastases from solid tumors: Experience with 90 patients. Cancer 1982, 49, 759-772. [CrossRef]

8. Hitchins, R.N.; Bell, D.R.; Woods, R.L.; Levi, J.A. A prospective randomized trial of single-agent versus combination chemotherapy in meningeal carcinomatosis. J. Clin. Oncol. 1987, 5, 1655-1662. [PubMed] 
9. Gwak, H.S.; Joo, J.; Kim, S.; Yoo, H.; Shin, S.H.; Han, J.Y.; Kim, H.T.; Lee, J.S.; Lee, S.H. Analysis of treatment outcomes of intraventricular chemotherapy in 105 patients for leptomeningeal carcinomatosis from non-small-cell lung cancer. J. Thorac. Oncol. 2013, 8, 599-605. [CrossRef] [PubMed]

10. Scott, B.J.; Oberheim-Bush, N.A.; Kesari, S. Leptomeningeal metastasis in breast cancer-A systematic review. Oncotarget 2016, 7, 3740-3747. [PubMed]

11. Glantz, M.J.; van Horn, A.; Fisher, R.; Chamberlain, M.C. Route of intracerebrospinal fluid chemotherapy administration and efficacy of therapy in neoplastic meningitis. Cancer 2010, 116, 1947-1952. [CrossRef] [PubMed]

12. Grossman, S.A.; Finkelstein, D.M.; Ruckdeschel, J.C.; Trump, D.L.; Moynihan, T.; Ettinger, D.S. Randomized prospective comparison of intraventricular methotrexate and thiotepa in patients with previously untreated neoplastic meningitis. Eastern cooperative oncology group. J. Clin. Oncol. 1993, 11, 561-569. [PubMed]

13. Glantz, M.J.; LaFollette, S.; Jaeckle, K.A.; Shapiro, W.; Swinnen, L.; Rozental, J.R.; Phuphanich, S.; Rogers, L.R.; Gutheil, J.C.; Batchelor, T.; et al. Randomized trial of a slow-release versus a standard formulation of cytarabine for the intrathecal treatment of lymphomatous meningitis. J. Clin. Oncol. 1999, 17, 3110-3116. [PubMed]

14. Glantz, M.J.; Jaeckle, K.A.; Chamberlain, M.C.; Phuphanich, S.; Recht, L.; Swinnen, L.J.; Maria, B.; LaFollette, S.; Schumann, G.B.; Cole, B.F.; et al. A randomized controlled trial comparing intrathecal sustained-release cytarabine (DepoCyt) to intrathecal methotrexate in patients with neoplastic meningitis from solid tumors. Clin. Cancer Res. 1999, 5, 3394-3402. [PubMed]

15. Boogerd, W.; van den Bent, M.J.; Koehler, P.J.; Heimans, J.J.; van der Sande, J.J.; Aaronson, N.K.; Hart, A.A.; Benraadt, J.; Vecht, C.J. The relevance of intraventricular chemotherapy for leptomeningeal metastasis in breast cancer: A randomised study. Eur. J. Cancer 2004, 40, 2726-2733. [CrossRef] [PubMed]

16. Riess, J.W.; Nagpal, S.; Iv, M.; Zeineh, M.; Gubens, M.A.; Ramchandran, K.; Neal, J.W.; Wakelee, H.A. Prolonged survival of patients with non-small-cell lung cancer with leptomeningeal carcinomatosis in the modern treatment era. Clin. Lung Cancer 2014, 15, 202-206. [CrossRef] [PubMed]

17. Lee, S.J.; Lee, J.I.; Nam, D.H.; Ahn, Y.C.; Han, J.H.; Sun, J.M.; Ahn, J.S.; Park, K.; Ahn, M.J. Leptomeningeal carcinomatosis in non-small-cell lung cancer patients: Impact on survival and correlated prognostic factors. J. Thorac. Oncol. 2013, 8, 185-191. [CrossRef] [PubMed]

18. Du, C.; Hong, R.; Shi, Y.; Yu, X.; Wang, J. Leptomeningeal metastasis from solid tumors: A single center experience in Chinese patients. J. Neuro Oncol. 2013, 115, 285-291. [CrossRef] [PubMed]

19. Park, J.H.; Kim, Y.J.; Lee, J.O.; Lee, K.W.; Kim, J.H.; Bang, S.M.; Chung, J.H.; Kim, J.S.; Lee, J.S. Clinical outcomes of leptomeningeal metastasis in patients with non-small cell lung cancer in the modern chemotherapy era. Lung Cancer 2012, 76, 387-392. [CrossRef] [PubMed]

20. Chamberlain, M.C. Leptomeningeal metastasis. Semin. Neurol. 2010, 30, 236-244. [CrossRef] [PubMed]

21. Pavlidis, N. The diagnostic and therapeutic management of leptomeningeal carcinomatosis. Ann. Oncol. 2004, 15, iv285-iv291. [PubMed]

22. De Azevedo, C.R.; Cruz, M.R.; Chinen, L.T.; Peres, S.V.; Peterlevitz, M.A.; de Azevedo Pereira, A.E.; Fanelli, M.F.; Gimenes, D.L. Meningeal carcinomatosis in breast cancer: Prognostic factors and outcome. J. Neuro Oncol. 2011, 104, 565-572. [CrossRef] [PubMed]

23. Fizazi, K.; Asselain, B.; Vincent-Salomon, A.; Jouve, M.; Dieras, V.; Palangie, T.; Beuzeboc, P.; Dorval, T.; Pouillart, P. Meningeal carcinomatosis in patients with breast carcinoma: Clinical features, prognostic factors, and results of a high-dose intrathecal methotrexate regimen. Cancer 1996, 77, 1315-1323. [CrossRef]

24. Wang, P.; Piao, Y.; Zhang, X.; Li, W.; Hao, X. The concentration of CYFRA 21-1, NSE and CEA in cerebro-spinal fluid can be useful indicators for diagnosis of meningeal carcinomatosis of lung cancer. Cancer Biomark. A Dis. Markers 2013, 13, 123-130.

25. Groves, M.D.; Hess, K.R.; Puduvalli, V.K.; Colman, H.; Conrad, C.A.; Gilbert, M.R.; Weinberg, J.; Cristofanilli, M.; Yung, W.K.; Liu, T.J. Biomarkers of disease: Cerebrospinal fluid vascular endothelial growth factor (VEGF) and stromal cell derived factor (SDF)-1 levels in patients with neoplastic meningitis (nm) due to breast cancer, lung cancer and melanoma. J. Neuro Oncol. 2009, 94, 229-234. [CrossRef] [PubMed]

26. Lee, J.S.; Melisko, M.E.; Magbanua, M.J.; Kablanian, A.T.; Scott, J.H.; Rugo, H.S.; Park, J.W. Detection of cerebrospinal fluid tumor cells and its clinical relevance in leptomeningeal metastasis of breast cancer. Breast Cancer Res. Treat. 2015, 154, 339-349. [CrossRef] [PubMed]

27. De Mattos-Arruda, L.; Mayor, R.; Ng, C.K.; Weigelt, B.; Martinez-Ricarte, F.; Torrejon, D.; Oliveira, M.; Arias, A.; Raventos, C.; Tang, J.; et al. Cerebrospinal fluid-derived circulating tumour DNA better represents the genomic alterations of brain tumours than plasma. Nat. Commun. 2015, 6, 8839. [CrossRef] [PubMed] 
28. Freilich, R.J.; Krol, G.; Deangelis, L.M. Neuroimaging and cerebrospinal fluid cytology in the diagnosis of leptomeningeal metastasis. Ann. Neurol. 1995, 38, 51-57. [CrossRef] [PubMed]

29. Collie, D.A.; Brush, J.P.; Lammie, G.A.; Grant, R.; Kunkler, I.; Leonard, R.; Gregor, A.; Sellar, R.J. Imaging features of leptomeningeal metastases. Clin. Radiol. 1999, 54, 765-771. [CrossRef]

30. Straathof, C.S.; de Bruin, H.G.; Dippel, D.W.; Vecht, C.J. The diagnostic accuracy of magnetic resonance imaging and cerebrospinal fluid cytology in leptomeningeal metastasis. J. Neurol. 1999, 246, 810-814. [CrossRef] [PubMed]

31. Pauls, S.; Fischer, A.C.; Brambs, H.J.; Fetscher, S.; Hoche, W.; Bommer, M. Use of magnetic resonance imaging to detect neoplastic meningitis: Limited use in leukemia and lymphoma but convincing results in solid tumors. Eur. J. Radiol. 2012, 81, 974-978. [CrossRef] [PubMed]

32. An, Y.J.; Cho, H.R.; Kim, T.M.; Keam, B.; Kim, J.W.; Wen, H.; Park, C.K.; Lee, S.H.; Im, S.A.; Kim, J.E.; et al. An NMR metabolomics approach for the diagnosis of leptomeningeal carcinomatosis in lung adenocarcinoma cancer patients. Int. J. Cancer. 2015, 136, 162-171. [CrossRef] [PubMed]

33. Hawkins, B.T.; Davis, T.P. The blood-brain barrier/neurovascular unit in health and disease. Pharmacol. Rev. 2005, 57, 173-185. [CrossRef] [PubMed]

34. Regina, A.; Demeule, M.; Laplante, A.; Jodoin, J.; Dagenais, C.; Berthelet, F.; Moghrabi, A.; Beliveau, R. Multidrug resistance in brain tumors: Roles of the blood-brain barrier. Cancer Metastasis Rev. 2001, 20, 13-25. [CrossRef] [PubMed]

35. Zhang, R.D.; Price, J.E.; Fujimaki, T.; Bucana, C.D.; Fidler, I.J. Differential permeability of the blood-brain barrier in experimental brain metastases produced by human neoplasms implanted into nude mice. Am. J. Pathol. 1992, 141, 1115-1124. [PubMed]

36. Wu, P.F.; Lin, C.H.; Kuo, C.H.; Chen, W.W.; Yeh, D.C.; Liao, H.W.; Huang, S.M.; Cheng, A.L.; Lu, Y.S. A pilot study of bevacizumab combined with etoposide and cisplatin in breast cancer patients with leptomeningeal carcinomatosis. BMC Cancer 2015, 15, 299. [CrossRef] [PubMed]

37. Berweiler, U.; Krone, A.; Tonn, J.C. Reservoir systems for intraventricular chemotherapy. J. Neuro Oncol. 1998, 38, 141-143. [CrossRef]

38. Sandberg, D.I.; Bilsky, M.H.; Souweidane, M.M.; Bzdil, J.; Gutin, P.H. Ommaya reservoirs for the treatment of leptomeningeal metastases. Neurosurgery 2000, 47, 49-54. [PubMed]

39. Glantz, M.J.; Hall, W.A.; Cole, B.F.; Chozick, B.S.; Shannon, C.M.; Wahlberg, L.; Akerley, W.; Marin, L.; Choy, H. Diagnosis, management, and survival of patients with leptomeningeal cancer based on cerebrospinal fluid-flow status. Cancer 1995, 75, 2919-2931. [CrossRef]

40. Kim, D.Y.; Lee, K.W.; Yun, T.; Park, S.R.; Jung, J.Y.; Kim, D.W.; Kim, T.Y.; Heo, D.S.; Bang, Y.J.; Kim, N.K. Comparison of intrathecal chemotherapy for leptomeningeal carcinomatosis of a solid tumor: Methotrexate alone versus methotrexate in combination with cytosine arabinoside and hydrocortisone. Jpn. J. Clin. Oncol. 2003, 33, 608-612. [CrossRef] [PubMed]

41. Chamberlain, M.C.; Kormanik, P.A.; Barba, D. Complications associated with intraventricular chemotherapy in patients with leptomeningeal metastases. J. Neurosurg. 1997, 87, 694-699. [CrossRef] [PubMed]

42. Morris, P.G.; Reiner, A.S.; Szenberg, O.R.; Clarke, J.L.; Panageas, K.S.; Perez, H.R.; Kris, M.G.; Chan, T.A.; DeAngelis, L.M.; Omuro, A.M. Leptomeningeal metastasis from non-small cell lung cancer: Survival and the impact of whole brain radiotherapy. J. Thorac. Oncol. 2012, 7, 382-385. [CrossRef] [PubMed]

43. Rudnicka, H.; Niwinska, A.; Murawska, M. Breast cancer leptomeningeal metastasis-The role of multimodality treatment. J. Neuro Oncol. 2007, 84, 57-62. [CrossRef] [PubMed]

44. Kennedy, B.C.; Brown, L.T.; Komotar, R.J.; McKhann, G.M. Frameless stereotactic Ommaya reservoir placement: Efficacy and complication comparison with frame-based technique. Stereotact. Funct. Neurosurg. 2016, 93, 415-418. [CrossRef] [PubMed]

45. Tanaka, T.; Matsuoka, M.; Sutani, A.; Gemma, A.; Maemondo, M.; Inoue, A.; Okinaga, S.; Nagashima, M.; Oizumi, S.; Uematsu, K.; et al. Frequency of and variables associated with the EGFR mutation and its subtypes. Int. J. Cancer 2010, 126, 651-655. [CrossRef] [PubMed]

46. Rosell, R.; Moran, T.; Queralt, C.; Porta, R.; Cardenal, F.; Camps, C.; Majem, M.; Lopez-Vivanco, G.; Isla, D.; Provencio, M.; et al. Screening for epidermal growth factor receptor mutations in lung cancer. N. Engl. J. Med. 2009, 361, 958-967. [CrossRef] [PubMed] 
47. Maemondo, M.; Inoue, A.; Kobayashi, K.; Sugawara, S.; Oizumi, S.; Isobe, H.; Gemma, A.; Harada, M.; Yoshizawa, H.; Kinoshita, I.; et al. Gefitinib or chemotherapy for non-small-cell lung cancer with mutated EGFR. N. Engl. J. Med. 2010, 362, 2380-2388. [CrossRef] [PubMed]

48. Mok, T.S.; Wu, Y.L.; Thongprasert, S.; Yang, C.H.; Chu, D.T.; Saijo, N.; Sunpaweravong, P.; Han, B.; Margono, B.; Ichinose, Y.; et al. Gefitinib or carboplatin-paclitaxel in pulmonary adenocarcinoma. N. Engl. J. Med. 2009, 361, 947-957. [CrossRef] [PubMed]

49. Eichler, A.F.; Kahle, K.T.; Wang, D.L.; Joshi, V.A.; Willers, H.; Engelman, J.A.; Lynch, T.J.; Sequist, L.V. EGFR mutation status and survival after diagnosis of brain metastasis in nonsmall cell lung cancer. Neuro-Oncol. 2010, 12, 1193-1199. [CrossRef] [PubMed]

50. Lee, D.W.; Shin, D.Y.; Kim, J.W.; Keam, B.; Kim, T.M.; Kim, H.J.; Kim, D.W.; Wu, H.G.; Paek, S.H.; Kim, Y.W.; et al. Additional prognostic role of EGFR activating mutations in lung adenocarcinoma patients with brain metastasis: Integrating with lung specific gpa score. Lung Cancer 2014, 86, 363-368. [CrossRef] [PubMed]

51. Liao, B.C.; Lee, J.H.; Lin, C.C.; Chen, Y.F.; Chang, C.H.; Ho, C.C.; Shih, J.Y.; Yu, C.J.; Yang, J.C. Epidermal growth factor receptor tyrosine kinase inhibitors for non-small-cell lung cancer patients with leptomeningeal carcinomatosis. J. Thorac. Oncol. 2015, 10, 1754-1761. [CrossRef] [PubMed]

52. Togashi, Y.; Masago, K.; Masuda, S.; Mizuno, T.; Fukudo, M.; Ikemi, Y.; Sakamori, Y.; Nagai, H.; Kim, Y.H.; Katsura, T.; et al. Cerebrospinal fluid concentration of gefitinib and erlotinib in patients with non-small cell lung cancer. Cancer Chemother. Pharmacol. 2012, 70, 399-405. [CrossRef] [PubMed]

53. Jackman, D.M.; Cioffredi, L.A.; Jacobs, L.; Sharmeen, F.; Morse, L.K.; Lucca, J.; Plotkin, S.R.; Marcoux, P.J.; Rabin, M.S.; Lynch, T.J.; et al. A phase I trial of high dose gefitinib for patients with leptomeningeal metastases from non-small cell lung cancer. Oncotarget 2015, 6, 4527-4536. [CrossRef] [PubMed]

54. Kawamura, T.; Hata, A.; Takeshita, J.; Fujita, S.; Hayashi, M.; Tomii, K.; Katakami, N. High-dose erlotinib for refractory leptomeningeal metastases after failure of standard-dose EGFR-TKIs. Cancer Chemother. Pharmacol. 2015, 75, 1261-1266. [CrossRef] [PubMed]

55. Lee, E.; Keam, B.; Kim, D.W.; Kim, T.M.; Lee, S.H.; Chung, D.H.; Heo, D.S. Erlotinib versus gefitinib for control of leptomeningeal carcinomatosis in non-small-cell lung cancer. J. Thorac. Oncol. 2013, 8, 1069-1074. [CrossRef] [PubMed]

56. Hoffknecht, P.; Tufman, A.; Wehler, T.; Pelzer, T.; Wiewrodt, R.; Schutz, M.; Serke, M.; Stohlmacher-Williams, J.; Marten, A.; Maria Huber, R.; et al. Efficacy of the irreversible ErbB family blocker afatinib in epidermal growth factor receptor (EGFR) tyrosine kinase inhibitor (TKI)-pretreated non-small-cell lung cancer patients with brain metastases or leptomeningeal disease. J. Thorac. Oncol. 2015, 10, 156-163. [CrossRef] [PubMed]

57. Nanjo, S.; Ebi, H.; Arai, S.; Takeuchi, S.; Yamada, T.; Mochizuki, S.; Okada, Y.; Nakada, M.; Murakami, T.; Yano, S. High efficacy of third generation EGFR inhibitor azd9291 in a leptomeningeal carcinomatosis model with EGFR-mutant lung cancer cells. Oncotarget 2016, 7, 3847-3856. [PubMed]

58. Yang, J.C.-H.; Kim, D.-W.; Kim, S.-W.; Cho, B.C.; Lee, J.-S.; Ye, X.; Yin, X.; Yang, Z.; Jiang, H.; Ahn, M.-J. Osimertinib activity in patients (pts) with leptomeningeal (LM) disease from non-small cell lung cancer (NSCLC): Updated results from bloom, a phase I study. In Proceeding of the Annual Meeting of the American Society of Clinical Oncology, McCormick Place, Chicago, IL, USA, 3-7 June 2016; p. 9002.

59. Ahn, M.-J.; Kim, D.-W.; Kim, T.M.; Lin, C.-C.; Ratnayake, J.; Carlie, D.J.; Yin, X.; Yang, Z.; Jiang, H.; Yang, J.C.-H. Phase I study of AZD3759, a CNS penetrable EGFR inhibitor, for the treatment of non-small-cell lung cancer (NSCLC) with brain metastasis (BM) and leptomeningeal metastasis (LM). In Proceeding of the Annual Meeting of the American Society of Clinical Oncology, McCormick Place, Chicago, IL, USA, 3-7 June 2016; p. 9003.

60. Solomon, B.; Varella-Garcia, M.; Camidge, D.R. ALK gene rearrangements: A new therapeutic target in a molecularly defined subset of non-small cell lung cancer. J. Thorac. Oncol. 2009, 4, 1450-1454. [CrossRef] [PubMed]

61. Solomon, B.J.; Mok, T.; Kim, D.W.; Wu, Y.L.; Nakagawa, K.; Mekhail, T.; Felip, E.; Cappuzzo, F.; Paolini, J.; Usari, T.; et al. First-line crizotinib versus chemotherapy in ALK-positive lung cancer. N. Engl. J. Med. 2014, 371, 2167-2177. [CrossRef] [PubMed]

62. Gainor, J.F.; Ou, S.H.; Logan, J.; Borges, L.F.; Shaw, A.T. The central nervous system as a sanctuary site in ALK-positive non-small-cell lung Cancer. J. Thorac. Oncol. 2013, 8, 1570-1573. [CrossRef] [PubMed]

63. Costa, D.B.; Kobayashi, S.; Pandya, S.S.; Yeo, W.L.; Shen, Z.; Tan, W.; Wilner, K.D. CSF concentration of the anaplastic lymphoma kinase inhibitor crizotinib. J. Clin. Oncol. 2011, 29, e443-e445. [CrossRef] [PubMed] 
64. Shaw, A.T.; Kim, D.W.; Mehra, R.; Tan, D.S.; Felip, E.; Chow, L.Q.; Camidge, D.R.; Vansteenkiste, J.; Sharma, S.; de Pas, T.; et al. Ceritinib in ALK-rearranged non-small-cell lung cancer. N. Engl. J. Med. 2014, 370, 1189-1197. [CrossRef] [PubMed]

65. Arrondeau, J.; Ammari, S.; Besse, B.; Soria, J.C. LDK378 compassionate use for treating carcinomatous meningitis in an ALK translocated non-small-cell lung cancer. J. Thorac. Oncol. 2014, 9, e62-e63. [CrossRef] [PubMed]

66. Ou, S.H.; Ahn, J.S.; de Petris, L.; Govindan, R.; Yang, J.C.; Hughes, B.; Lena, H.; Moro-Sibilot, D.; Bearz, A.; Ramirez, S.V.; et al. Alectinib in crizotinib-refractory $A L K$-rearranged non-small-cell lung cancer: A phase II global study. J. Clin. Oncol. 2016, 34, 661-668. [CrossRef] [PubMed]

67. Shaw, A.T.; Gandhi, L.; Gadgeel, S.; Riely, G.J.; Cetnar, J.; West, H.; Camidge, D.R.; Socinski, M.A.; Chiappori, A.; Mekhail, T.; et al. Alectinib in ALK-positive, crizotinib-resistant, non-small-cell lung cancer: A single-group, multicentre, phase 2 trial. Lancet Oncol. 2016, 17, 234-242. [CrossRef]

68. Gadgeel, S.M.; Gandhi, L.; Riely, G.J.; Chiappori, A.A.; West, H.L.; Azada, M.C.; Morcos, P.N.; Lee, R.M.; Garcia, L.; Yu, L.; et al. Safety and activity of alectinib against systemic disease and brain metastases in patients with crizotinib-resistant $A L K$-rearranged non-small-cell lung cancer (AF-002JG): Results from the dose-finding portion of a phase $1 / 2$ study. Lancet Oncol. 2014, 15, 1119-1128. [CrossRef]

69. Ou, S.H.; Sommers, K.R.; Azada, M.C.; Garon, E.B. Alectinib induces a durable (>15 months) complete response in an $A L K$-positive non-small cell lung cancer patient who progressed on crizotinib with diffuse leptomeningeal carcinomatosis. Oncologist 2015, 20, 224-226. [CrossRef] [PubMed]

70. Gainor, J.F.; Sherman, C.A.; Willoughby, K.; Logan, J.; Kennedy, E.; Brastianos, P.K.; Chi, A.S.; Shaw, A.T. Alectinib salvages cns relapses in $A L K$-positive lung cancer patients previously treated with crizotinib and ceritinib. J. Thorac. Oncol. 2015, 10, 232-236. [CrossRef] [PubMed]

71. Kort, A.; Sparidans, R.W.; Wagenaar, E.; Beijnen, J.H.; Schinkel, A.H. Brain accumulation of the EML4-ALK inhibitor ceritinib is restricted by p-glycoprotein (P-GP/ABCB1) and breast cancer resistance protein (BCRP/ABCG2). Pharmacol. Res. 2015, 102, 200-207. [CrossRef] [PubMed]

72. Tang, S.C.; Nguyen, L.N.; Sparidans, R.W.; Wagenaar, E.; Beijnen, J.H.; Schinkel, A.H. Increased oral availability and brain accumulation of the ALK inhibitor crizotinib by coadministration of the P-glycoprotein (ABCB1) and breast cancer resistance protein (ABCG2) inhibitor elacridar. Int. J. Cancer 2014, 134, 1484-1494. [CrossRef] [PubMed]

73. Kodama, T.; Hasegawa, M.; Takanashi, K.; Sakurai, Y.; Kondoh, O.; Sakamoto, H. Antitumor activity of the selective ALK inhibitor alectinib in models of intracranial metastases. Cancer Chemother. Pharmacol. 2014, 74, 1023-1028. [CrossRef] [PubMed]

74. Slamon, D.J.; Clark, G.M.; Wong, S.G.; Levin, W.J.; Ullrich, A.; McGuire, W.L. Human breast cancer: Correlation of relapse and survival with amplification of the HER-2/neu oncogene. Science 1987, 235, 177-182. [CrossRef] [PubMed]

75. Ross, J.S.; Fletcher, J.A. The HER-2/neu oncogene in breast cancer: Prognostic factor, predictive factor, and target for therapy. Oncologist 1998, 3, 237-252. [PubMed]

76. Slamon, D.J.; Leyland-Jones, B.; Shak, S.; Fuchs, H.; Paton, V.; Bajamonde, A.; Fleming, T.; Eiermann, W.; Wolter, J.; Pegram, M.; et al. Use of chemotherapy plus a monoclonal antibody against HER2 for metastatic breast cancer that overexpresses HER2. N. Engl. J. Med. 2001, 344, 783-792. [CrossRef] [PubMed]

77. Zagouri, F.; Sergentanis, T.N.; Bartsch, R.; Berghoff, A.S.; Chrysikos, D.; de Azambuja, E.; Dimopoulos, M.A.; Preusser, M. Intrathecal administration of trastuzumab for the treatment of meningeal carcinomatosis in HER2-positive metastatic breast cancer: A systematic review and pooled analysis. Breast Cancer Res. Treat. 2013, 139, 13-22. [CrossRef] [PubMed]

78. Pestalozzi, B.C.; Brignoli, S. Trastuzumab in CSF. J. Clin. Oncol. 2000, 18, 2349-2351. [PubMed]

79. Stemmler, H.J.; Schmitt, M.; Willems, A.; Bernhard, H.; Harbeck, N.; Heinemann, V. Ratio of trastuzumab levels in serum and cerebrospinal fluid is altered in HER2-positive breast cancer patients with brain metastases and impairment of blood-brain barrier. Anti-Cancer Drugs 2007, 18, 23-28. [CrossRef] [PubMed]

80. Mego, M.; Sycova-Mila, Z.; Obertova, J.; Rajec, J.; Liskova, S.; Palacka, P.; Porsok, S.; Mardiak, J. Intrathecal administration of trastuzumab with cytarabine and methotrexate in breast cancer patients with leptomeningeal carcinomatosis. Breast 2011, 20, 478-480. [CrossRef] [PubMed]

81. Ferrario, C.; Davidson, A.; Bouganim, N.; Aloyz, R.; Panasci, L.C. Intrathecal trastuzumab and thiotepa for leptomeningeal spread of breast cancer. Ann. Oncol. 2009, 20, 792-795. [CrossRef] [PubMed] 
82. Mir, O.; Ropert, S.; Alexandre, J.; Lemare, F.; Goldwasser, F. High-dose intrathecal trastuzumab for leptomeningeal metastases secondary to HER-2 overexpressing breast cancer. Ann. Oncol. 2008, 19, 1978-1980. [CrossRef] [PubMed]

83. Stemmler, H.J.; Mengele, K.; Schmitt, M.; Harbeck, N.; Laessig, D.; Herrmann, K.A.; Schaffer, P.; Heinemann, V. Intrathecal trastuzumab (herceptin) and methotrexate for meningeal carcinomatosis in HER2-overexpressing metastatic breast cancer: A case report. Anti-Cancer Drugs 2008, 19, 832-836. [CrossRef] [PubMed]

84. Kordbacheh, T.; Law, W.Y.; Smith, I.E. Sanctuary site leptomeningeal metastases in HER-2 positive breast cancer: A review in the era of trastuzumab. Breast 2016, 26, 54-58. [CrossRef] [PubMed]

85. Raizer, J.; Pentsova, E.; Omuro, A.; Lin, N.; Nayak, L.; Quant, E.; Kumthekar, P. Phase I trial of intrathecal trastuzumab in HER2 positive leptomeningeal metastases. Neuro-Oncol. 2014, 16, 19. [CrossRef]

86. Rusnak, D.W.; Affleck, K.; Cockerill, S.G.; Stubberfield, C.; Harris, R.; Page, M.; Smith, K.J.; Guntrip, S.B.; Carter, M.C.; Shaw, R.J.; et al. The characterization of novel, dual ErbB-2/EGFR, tyrosine kinase inhibitors: Potential therapy for cancer. Cancer Res. 2001, 61, 7196-7203. [PubMed]

87. Geyer, C.E.; Forster, J.; Lindquist, D.; Chan, S.; Romieu, C.G.; Pienkowski, T.; Jagiello-Gruszfeld, A.; Crown, J.; Chan, A.; Kaufman, B.; et al. Lapatinib plus capecitabine for HER2-positive advanced breast cancer. N. Engl. J. Med. 2006, 355, 2733-2743. [CrossRef] [PubMed]

88. Bachelot, T.; Romieu, G.; Campone, M.; Dieras, V.; Cropet, C.; Dalenc, F.; Jimenez, M.; Le Rhun, E.; Pierga, J.Y.; Goncalves, A.; et al. Lapatinib plus capecitabine in patients with previously untreated brain metastases from HER2-positive metastatic breast cancer (landscape): A single-group phase 2 study. Lancet Oncol. 2013, 14, 64-71. [CrossRef]

89. Pivot, X.; Manikhas, A.; Zurawski, B.; Chmielowska, E.; Karaszewska, B.; Allerton, R.; Chan, S.; Fabi, A.; Bidoli, P.; Gori, S.; et al. Cerebel (EGF111438): A phase III, randomized, open-label study of lapatinib plus capecitabine versus trastuzumab plus capecitabine in patients with human epidermal growth factor receptor 2-positive metastatic breast cancer. J. Clin. Oncol. 2015, 33, 1564-1573. [CrossRef] [PubMed]

90. Coiffier, B.; Lepage, E.; Briere, J.; Herbrecht, R.; Tilly, H.; Bouabdallah, R.; Morel, P.; van den Neste, E.; Salles, G.; Gaulard, P.; et al. Chop chemotherapy plus rituximab compared with chop alone in elderly patients with diffuse large-B-cell lymphoma. N. Engl. J. Med. 2002, 346, 235-242. [CrossRef] [PubMed]

91. Feugier, P.; Virion, J.M.; Tilly, H.; Haioun, C.; Marit, G.; Macro, M.; Bordessoule, D.; Recher, C.; Blanc, M.; Molina, T.; et al. Incidence and risk factors for central nervous system occurrence in elderly patients with diffuse large-B-cell lymphoma: Influence of Rituximab. Ann. Oncol. 2004, 15, 129-133. [CrossRef] [PubMed]

92. Rubenstein, J.L.; Combs, D.; Rosenberg, J.; Levy, A.; McDermott, M.; Damon, L.; Ignoffo, R.; Aldape, K.; Shen, A.; Lee, D.; et al. Rituximab therapy for cns lymphomas: Targeting the leptomeningeal compartment. Blood 2003, 101, 466-468. [CrossRef] [PubMed]

93. Rubenstein, J.L.; Fridlyand, J.; Abrey, L.; Shen, A.; Karch, J.; Wang, E.; Issa, S.; Damon, L.; Prados, M.; McDermott, M.; et al. Phase I study of intraventricular administration of rituximab in patients with recurrent cns and intraocular lymphoma. J. Clin. Oncol. 2007, 25, 1350-1356. [CrossRef] [PubMed]

94. Schulz, H.; Pels, H.; Schmidt-Wolf, I.; Zeelen, U.; Germing, U.; Engert, A. Intraventricular treatment of relapsed central nervous system lymphoma with the anti-CD20 antibody rituximab. Haematologica 2004, 89, 753-754. [PubMed]

95. Floudas, C.S.; Chandra, A.B.; Xu, Y. Vemurafenib in leptomeningeal carcinomatosis from melanoma: A case report of near-complete response and prolonged survival. Melanoma Res. 2016, 26, 312-315. [CrossRef] [PubMed]

96. Sakji-Dupre, L.; Le Rhun, E.; Templier, C.; Desmedt, E.; Blanchet, B.; Mortier, L. Cerebrospinal fluid concentrations of vemurafenib in patients treated for brain metastatic BRAF-v600 mutated melanoma. Melanoma Res. 2015, 25, 302-305. [CrossRef] [PubMed]

(C) 2016 by the authors; licensee MDPI, Basel, Switzerland. This article is an open access article distributed under the terms and conditions of the Creative Commons Attribution (CC-BY) license (http://creativecommons.org/licenses/by/4.0/). 